Tumor Biol 1989;10:60

\title{
Announcement
}

\section{Biology of Tumours}

Symposium is to be held in Turku (Finland), 6-8 July, 1989 as a Satellite Symposium of The XXXI International Congress of Physiological Sciences in Helsinki (Finland), 9-14 July, 1989

The Symposium of the Biology of Tumours will concentrate on the following aspects of tumour biology and physiology: Energy metabolism; Tumorous cell proliferation and development of metastases; Biotransformation; Reactive oxygen species; Membranes; Oncogenes, and Dietary aspects.

Deadline for abstracts and registration will be May 1, 1989. Contact persons: Dr. Matti Laitinen, Turku University Hospital, Central Laboratory, SF-20520 Turku, Finland, or Dr. Eino Hietanen, Int. Agency for Res. on Cancer, 150, cours Albert-Thomas, F-69372 Lyon Cedex 08, France. 